\title{
Ecosystem of the Niger Delta region of Nigeria: Potentials and Threats
}

\begin{abstract}
The Niger Delta region has several ecosystems that play essential role for the sustenance of the different habitats and life forms in the area. Some of the notable ecosystem includes freshwater swamp forest, lowland rainforest, mangroves forest etc. In recent time, the rate of deforestation, excessive hunting of wildlife, bush burning, and intensive agricultural practices has increased in the region. This study reviews the potentials and threats of Niger Delta ecosystem region of Nigeria. The study found that the rate of deforestation and other human activities in the area is having an impact on the various ecosystems in the Niger Delta. These impacts could be affecting biodiversity of the area including mammals, reptiles, amphibians, birds, etc with regard to species diversity and population status. Furthermore, other role played by the various ecosystem including source of medicinal plants, spawning ground for fisheries, breeding and nestling ground for migratory birds, shoreline protection, habitats for wildlife, among others are under intense threat. Therefore, there is the need for improved enforcement, surveillance of the various the international and national legislations concerning biodiversity conservation and protection.
\end{abstract}

Volume 2 Issue 4 - 2018

\section{Sylvester Chibueze Izah}

Department of Biological Sciences, Niger Delta University, Nigeria

Correspondence: Sylvester Chibueze Izah, Department of Biological Sciences, Faculty of Science, Niger Delta University, Wilberforce Island, Bayelsa State, Nigeria, Tel +234 7030192466 Email chivestizah@gmail.com

Received: April 19,2018 | Published: July 26, 2018

Keywords: anthropogenic activities; biodiversity; conservation; ecology; wetland protection

\section{Introduction}

Nigeria has a land mass of $923,770 \mathrm{~km}^{2}$ and is bordered to the north by Niger and Chad Republics, East by Cameroon and southern most part by Atlantic Ocean. ${ }^{1}$ Nigeria is the most populated country in Africa with about 180 million persons. According to Idu, ${ }^{1}$ Nigeria is one of the largest populated country in the world, and about $1 / 4$ of total Sub-Sahara African population. Nigeria is blessed with arable land for agricultural purposes, crude oil and natural gas deposits, and other minerals resources such as tin, iron ore, coal, lead, zinc, limestone, niobium etc. In addition, Nigeria has several water bodies which are distributed as freshwater (river, creek, creek lets, ponds, lakes and streams), estuarine (fresh and salt water interphase) and marine/salt water. ${ }^{2-5}$ The soil of the region varies according to types viz: clay, silts and sand. The soil is a major direct recipient of human activities including food processing such as cassava processing,,${ }^{6,7}$ oil palm processing; ${ }^{8}$ wastes from different settings including municipal wastes.

The aquatic ecosystem is also habitats to several biological species including fisheries (viz: both fin and shelled fish), some aquatic mammals, reptiles etc. ${ }^{2,3}$ Furthermore, in most static freshwater resources especially in Baylesa state, aquatic insects, some species of snails, freshwater shrimps, snakes and fishes like catfish; algae, water lilies, water hyacinths and lettuce are frequently found in such habitats. While in flowing water bodies such as rivers, several species of fishes and macrophytes are found in the freshwater system. Animals including sharks, whales, dolphins are some diversity found in the marine ecosystems.

Nearly $2.6-3.0 \%$ of Nigerian land mass is wetlands ${ }^{2,9,10}$ especially in the Niger Delta region. ${ }^{11,12}$ According to Ramsar Convention, wetlands are characterized by marsh, fern, water/peatland which are either natural or artificial, permanent or temporary, with static or flowing water which can either be estuarine, fresh or marine with a depth of $\leq 6$ meters at low tide. ${ }^{2,13-16}$ According to Olalekan et al., ${ }^{17}$ wetlands (which are classified as bog, marsh, or swamp based on the floral habitat and associated soil characteristics) are terrestrial or semi-terrestrial ecosystem with low drainage quality, slow flowing water or stagnant water bodies. Ohimain \& Akinnibosun ${ }^{16}$ reported that wetlands is a habitats to so many life forms that can adapt in anoxic environment especially macrophytes.

Nigerian has several species of wildlife comprising of about 7,895 plant species (which are distributed into 338 families and 2,215 genera), over 22, 000 vertebrates and invertebrates species (including 20, 000 insects, about 1000 birds, about 1, 000 fishes, 247 mammals and 123 reptiles), 1,489 species of micro-organisms. ${ }^{12,18,19}$ The authors reported that out of the wildlife diversity of Nigeria, about $0.14 \%$ and $0.22 \%$ is threatened and endangered, respectively. ${ }^{12}$ In attempts to protect biodiversity, Nigeria established several protected area including 8 national Parks, 445 forest reserves, 12 strict nature reserves and 28 game reserves. ${ }^{19}$

Typically, Niger Delta consists of mangrove, lowland rainforest freshwater forest and aquatic ecosystem that provide services to the indigene of the region and to the West African economy at large. ${ }^{20}$ Several biodiversity is found in the Niger Delta region. ${ }^{11,12}$ Biodiversity play several ecological, social and economic roles to mankind. For instance, insects play essential role in pollination processes, wildlife are source of protein, hides and skin, while plant resources are utilized for construction works as timber, shrubs and herbs are mostly used for the treatment of several sickness and diseases. ${ }^{2}$ Izah \& Seiyaboh ${ }^{12}$ also reported that several wildlifes have medicinal potentials. Probably due to these roles, Ibimilua ${ }^{21}$ described biodiversity as life-sustaining system in the biosphere. But at present several human activities is 
having an impact on the ecosystem. Therefore, this study focused on the Niger Delta Ecosystem with regard to its potentials and threats.

\section{Some major Niger delta ecosystem}

According to Igu \& Marchant, ${ }^{22}$ the Niger Delta is predominantly a flat, low-lying sedimentary basin drained by the Niger River with several crisscrossed rivers, streams, creeks, creeklets that emptied into the Atlantic Ocean through the estuaries. Authors have variously reported that the Niger Delta region (comprising of Ondo, Edo, Delta, Bayelsa, Rivers, Imo, Rivers, Abia, Akwa-Ibom and Cross Rivers states) of Nigeria consist of approximately $70,000 \mathrm{~km}^{2}$ is the largest wetland in Africa ${ }^{23,24}$ and third largest in the world. ${ }^{11,24,25}$ Approximately 2,370 square kilometers of the Niger Delta region includes rivers, creeks and estuaries and 8,600 square kilometers is made up of stagnant swamp. ${ }^{26,27}$ Probably due to the nature of the area, the major distinct ecosystem found in the zone include barrier islands, estuaries, mangroves, freshwater swamps, lowland rainforests, creeks and creeklets. ${ }^{2,23,28}$ Specifically, studies have mentioned the presence of six different ecological zones including rainforest, mangrove, flood forest zone, eastern flank, marsh forest zone and barrier islands. ${ }^{29,30}$ Another study has classified the ecosystem to include rainforest, mangrove, freshwater swamps, mountain region and derived savannah. ${ }^{30,31}$ This suggests slight variation in author's opinion about different ecological zone in the Niger Delta. Typically, with the major ecological zones previously mentioned, many of them fall within the mangroves (estuarine, marine, barrier Island), freshwater forest and low land rainforest ecosystem. According to Akachi, ${ }^{26}$ the Niger Delta ecosystem is highly diverse and can support several terrestrial and aquatic life forms.

Ayanlade $^{30}$ further reported 7 land use change in the Niger Delta including urban (comprising land for residential, commercial services, industrial, transportation, communications, industrial mixed urban and rural build-up land), farmland (comprising of agricultural pasture, and bare fields within a farmland), water (involving stable and permanent surface water such as lakes, reservoirs, streams, estuaries and ocean), mangrove (an area involving brackish swamp and beach forests with red and white mangroves and some protected area), lowland rainforest (with protected areas), freshwater forest (with protected areas) and bare ground (which are open lands without vegetal cover). Between 1987-2011, several land changes value occurred in the Niger Delta (Figure 1) (Figure 2) (Figure 3). Hence, the three major ecosystem of the Niger Delta including mangroves, lowland rainforest and freshwater forest are discussed in this subsection.

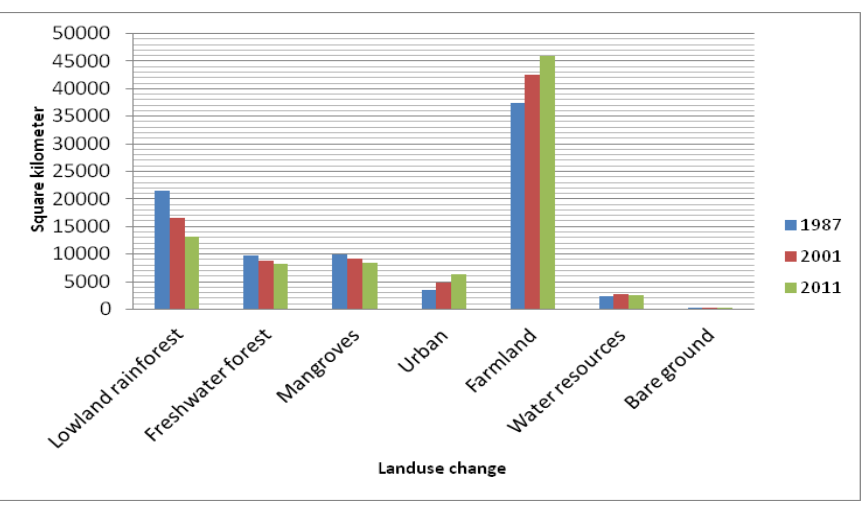

Figure I Land use change in the Niger Delta between 1987-20I I. Adapted from. ${ }^{30}$

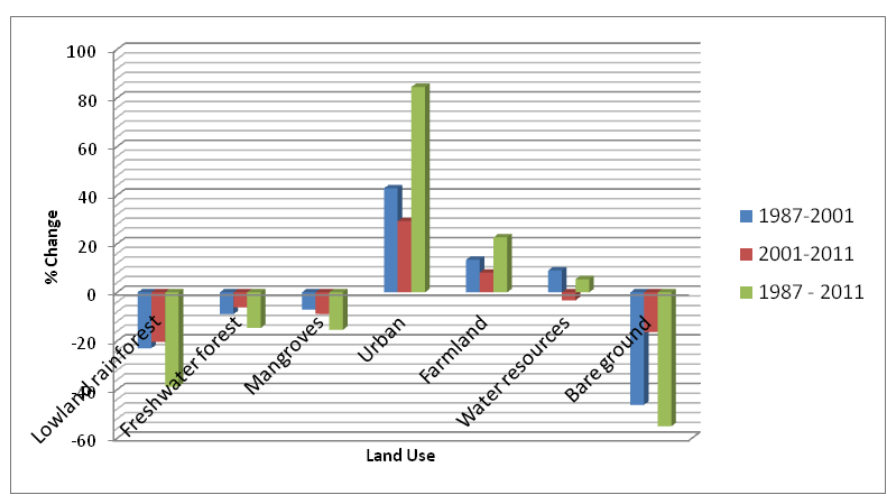

Figure 2 Percentage landuse change in the Niger Delta between I987-20I I. Adapted from. 30

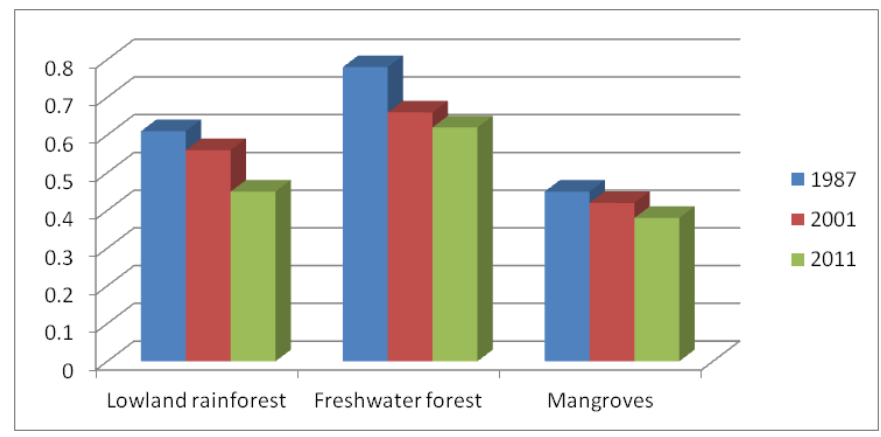

Figure 3 Normalized Difference Vegetation Index (NDVI) for different forest types in the Niger Delta between 1987-20I I. Adapted from.30

\section{Lowland rainforest}

The lowland rainforest is among the complex ecological zones in the Niger Delta with regard to diversity of species. According to Ayanlade, ${ }^{30}$ the rainforest zone is characterized by tall trees ( $1{ }^{\text {st }}$ layer/ stratum which is characterized by thick/dense forest with smooth bark trees of about 40 to 50 metre tall and often a times, epiphytes and lianas are attached to the back of the tree), big trees with canopy $\left(2^{\text {nd }}\right.$ layer/ stratum which are plants with high branch, 20-35metre tall and can provide shade), lower trees with bare trunks ( $3^{\text {rd }}$ layer/ stratum which are plant that about 20 metre tall) and $4^{\text {th }}$ layer which areas with mosses, small stemmed shrubs, lichens, herbs and ferns) ( $4^{\text {th }}$ layer/stratum). The vegetation found in rainforest are mainly used for timber, firewood, saw wood, particleboard, pulp/paper, poles and traditional medicine and some of the commonly found species include Khaya ivorensis, Guarea thompsonii, Entandophragma cylindricum, Entandrophragma angolense, Guarea cedrata, Lovoa trichilioides, Gossweilerodendron balsamiferum, Milicia excelsa, Terminalia ivorensis, Triplochiton scleroxylon and Terminalia superba. ${ }^{30}$

\section{Mangroves ecosystem (estuarine and marine)}

Brackish water is also referred as estuarine (salt and fresh water interphase $)^{2}$ and they compromises of part of the Niger Delta mangroves. Typically, the Niger Delta mangroves is one of the largest in Africa. In estuarine, the salinity level is lower than that of marine water but higher than that of freshwater. The area is dominated by some mangroves plants with narrow strip of beach ridges. Jamabo \& Chinda, ${ }^{32}$ Ogamba et al., ${ }^{33}$ Ohimain et al. ${ }^{34}$ reported Niger Delta mangroves to include Rhizophora racemosa (tall red mangrove), $R$. mangle and Rhizophora harrisonii (short red mangrove), Avicennia 
germinans (white mangrove), and Laguncularia racemosa etc. Typically the genus Rhizophora and Avicennia account for a significant mangrove species found in the Niger Delta region. In the Niger Delta, freshwater $\left(10,000 \mathrm{~km}^{2}\right)$ and mangroves are separated by transition wetlands dominated by Dalburger escatophylum, Machaerum lunatus and Pandanus sp. ${ }^{34}$ Other species such as Nypa fruticans are also found in the mangrove ecosystem of the Niger Delta.

In the brackish water resources in the Niger Delta, the predominant shell fish found include the genera Tympanotonus and Pachymelania, ${ }^{35}$ and within them Tympanotonus have one species with two varieties i.e. T. fuscatus var fuscatus and T. fuscatus var radula. ${ }^{33}$ T. fuscatus is predominantly found in the intertidal area rich in detritus and mud substratum where they co-habits with Neritina adansoniana and Pachymelania fusca var quadriseriata..$^{32,33}$ Apart from the shelled fish, several other fin fishes, planktons (phytoplankton and zooplanktons) and macro benthic organisms are found in both estuarine and marine ecosystem. Furthermore, mangroves protects the area against influx of saline water, and the plant is a potential source of timber, medicine, breeding ground for fisheries and specifically the tilt roots of the mangroves and mud surface usually support different species of oysters, crabs and other invertebrates. ${ }^{30}$

\section{Freshwater swamp}

In the Niger Delta, the freshwater swamp is situated between the lowland rain forest in the north and the mangrove swamp in the south. ${ }^{22}$ The freshwater forest swamps provides transition zone between the two ecosystems and a passageway for the migration of biodiversity. ${ }^{22}$ According to Ayanlade, ${ }^{30}$ the Niger Delta freshwater swamp is silt laden from River Niger. The freshwater swamp is essential habits for fisheries particularly during the flooding period. The freshwater is also an important habitat for crayfish, prawn, crabs and crocodile. ${ }^{22}$

The vegetation of freshwater forest characterized by tall trees such as Musanga cecropioides, Annona senegalensis, Anthocliesta vogelii, Eleais guineensis, Harungana madagascariensis, Juncus sp, Pandanus sp, Raphia hookeri, R. vinifera and Tectonia grandis. ${ }^{30}$ Majority of the plant species on the area is used as fuel food, medicine, boat carving and it's also protect the shoreline. ${ }^{30}$

Furthermore, freshwater are water resources that are mostly used for domestic purposes including drinking, bathing, cooking etc. The areas with freshwater resources are often referred to as freshwater swamps. Within the freshwater swamps, other habitats such as riparian and arable farmland are common. In the Niger Delta several studies have reported biodiversity in some freshwater swamps.

Niger Delta region has several freshwater creeks and creeklets, and they are called by several names. For instance, in Bayelsa state some notable water bodies include Epie creek, ${ }^{36}$ Sagbama creek, ${ }^{37,38}$ Ikoli creek, ${ }^{39-41}$ Kolo creek, ${ }^{42,43}$ Taylor creek, ${ }^{44}$ Nun River ${ }^{45-49}$ among others. Most fresh water resources in the area are linked to estuarine from where they emptied into the Ocean. The activities of makeshift oil refinery on Nun River estuary is having impact on the physicochemical characteristics of water, ${ }^{50}$ sediment ${ }^{51}$ and macro-invertebrates ${ }^{52}$ leading to severe impacts on mangroves plants and macro-invertebrates (such as Marphysa, Lumbrinereis, Lillyalla, Mandippi species, Marphysa sanguinae, Notomastus latericeus, Marianida pinniger, Littorina anguilifera, Neritina owenensis, Pachymelania aurita, Pachymelania bryonensis and Crassostrea gasari etc). ${ }^{52}$

In the Niger Delta, several macrophytes have been reported in surface water including Eichhornia crassipes, Nymphaea lotus, $N$. maculate, Pistia stratiotes, Salvinia nymphellula, Azolla pinnata var africana ${ }^{16,45,48,53}$ among others. In the terrestrial habitats several plant species have been reported in the area. In the terrestrial ecosystem of the freshwater swamps, several plant species have been reported in the Niger Delta region. The importance of freshwater swamp forest ecosystems is poorly studied, estimated and understood. ${ }^{22}$ The Niger Delta ecosystem is fragile with several useful resources for the people of the region, as such, exploring its sustainability will help to maximize the potential of the ecosystem. ${ }^{22}$

In addition to the three major ecosystems in the Niger Delta, derived savannah (comprising of different type grasses, shrub and relatively few trees) is also found in the northern parts of the region. According to Ayanlade, ${ }^{30}$ the savannah in the region may have derived from secondary rainforest which was reduced to open woodland due to agricultural activities, and consistent human activities; as such it becomes difficult for the trees in the area to mature. The authors further reported that land shortage due to population growth, industrialization and urbanization as major cause of derived savannah in the area.

\section{Status of Niger delta ecosystem}

The Niger Delta wetlands have been referred to as largest biodiversity hotspots in Africa that inhabit several species that are endemic in the region. ${ }^{2,11,12}$ Ogbe $^{23}$ also reported that several biodiversity that are internationally and locally endangered are also found in the Niger Delta region. Typically, biodiversity involves all species of life forms including plants, animals and microbes that play essential role in the ecosystem. ${ }^{2}$ Several species of plants, mammals, reptiles, avian fauna, amphibians, fisheries, insects, microbes have been reported in the Niger Delta ecosystem. For instance, Akani et al. ${ }^{54}$ reported the presence 28 species that belong to the genera Bufo, Nectophryne, Silurana, Hymenochirus, Hylarana, Ptychadena, Aubria, Conraua, Hoplobatrachus, Phrynobatrachus, Arthroleptis, Chiromantis, Phrynomantis, Hyperolius, Afrixalus, Leptopelis, Phlyctimantis, Opisthothylax around oil and gas facilities in four locations in southern Nigeria between 1996-2002.

Several species of biodiversity have been reported in the Niger Delta region, some are endemic while several others are threatened, endangered or critically endangered. ${ }^{11,12}$ According to Ikemeh, ${ }^{55}$ Niger Delta is home to some endemic species including Sclater's guenon (Cercopithecus sclateri), Nigerian white-throated guenon (Cercopithecus erythrogaster pococki), red-capped mangabey (Cercocebus torquatus) and the endangered Nigeria-Cameroon chimpanzee (Pan troglodytes ellioti). Furthermore, $\mathrm{WCS}^{56}$ also indicated that endemic Niger Delta Red Colobus monkey (Procolobus epieni), Nigerian white-throated guenon (Cercopithecus erythrogaster pococki) $)^{30,56}$ is also found in Apoi creek in Bayelsa state. Based on International Union for Conservation of Nature classification Procolobus epieni have been rated as 'Critically Endangered'. ${ }^{57}$ Furthermore, $\mathrm{WCS}^{56}$ rated the Niger Delta Colobus monkey as among the 25 endangered primates in the world. As such, Ikemeh ${ }^{55}$ is with the opinion that the fate of the monkey will be determined if proactive measures is taken towards sustainable conservation. Furthermore, other endemic mammals such as Heslop's pygmy hippopotamus (Hexaprotodon liberiensisheslopi) have gone on extinction in the Niger Delta probably due to their excessive exploitation..$^{55}$

In different locations in the Niger Delta region, biodiversity have been reported through survey, questionnaire, semi-structured 
interview and sighting (alive or dead as in bushmeat). ${ }^{11,12}$ In Bayelsa state, Akani et al. ${ }^{58}$ reported the presence 21 mammalian species sold in Swali market, Yenagoa, Bayelsa state as bush meat. Some other notable wildlife species sold alive in the market include Cercopithecus mona, Cercopithecus sclateri, Cercopithecus nictitans, pangolins. ${ }^{58}$ Furthermore, in Swali market, Thryonomys swinderianus, Cricetomys cf. emini, Atherurus africanus, Crossarchus platycephalus, antelopes, and monkeys were the predominant wildlife sold as bush meat. ${ }^{58}$ In Wilberforce Island, Bayelsa state, Ohimain et al. ${ }^{59}$ reported the presence of 45 mammal (in 21 families); 78 avian fauna (in 27 families); and over 56 species of plants. In Nun River forest reserve of Bayelsa state, Hamadina et al. ${ }^{60}$ also reported the presence of 36 mammals (belonging to 18 families); 18 reptiles (belonging to 12 families); 67 avian fauna (belonging to 25 families). In Edumanom Forest Reserve of Bayelsa State, two-spotted civet (Nandinia binotata) has been reported by Amadi et al. ${ }^{61}$ Akani et al. ${ }^{62}$ reported the presence of Raphia hookeri, Mitragyna ciliata, Nauclea diderrichii, Khaya ivorensis, Irvingia gabonensis, Eleais guineensis, Musanga cecropoides, ferns, epiphytes and macrophytes in freshwater forest resource of Taylor creek. The authors further reported the wildlife resources to comprise of 27 species of mammals, 34 species of reptiles and 10 species of amphibians using quantitative and qualitative approach. In Delta state, Lameed ${ }^{63}$ reported the presence of 47, 7, and 3 species of mammals, reptiles and amphibians in Kwale forest reserve and Okpai ecosystem. Furthermore, Lameed ${ }^{63}$ also reported that due to movement nature of birds, at different locations of the ecosystem varying species were found including 19 species in villages and farmlands, 49 species in forest area and 14 species around river bank and beaches.

Insects is another diversity that play essential ecological roles. ${ }^{11,12}$ Some insects are consumed intentionally and while several others are consumed unintentionally in some African countries including Nigeria ${ }^{64}$ Within the Niger Delta region several species of edible insects have been reported in literature for instance. Okore et al. ${ }^{65}$ reported the presence of Macrotermes species, Brachytrypes membranaceus, Zonocerus species, Rhynchophorus phoenicis, Rhinoceros oryctes, Heteroligus meles, Sitophilus oryzae, Callosobruchus maculatus, Dermestes maculatus, Daraba (Sceloides) laisalis, Gonimbrasia belina, Apis mellifera, Musca domestica and some other species of cotton stainer, aphids and locust in the Niger Delta. Like birds, their distribution and occurrence frequency shows high dissimilarity depending on the region and prevailing human activities of an area.

In different locations in the Niger Delta, several plant species have been reported. For instance, Ubom ${ }^{66}$ reported the presence of 339 plant species which are distributed into 88 families in some areas within the Niger Delta region. In different locations, several plant species have been reported. Eludoyin et al. ${ }^{67}$ reported the presence of 37 plant species with medicinal properties around University of Port Harcourt, Rivers state. Uzodimma ${ }^{68}$ also reported the presence of 72 plant species used by the indigenous people of Ogii in Okigwe, Imo State for the treatment of different type of ailments.

\section{Potentials of Niger delta wetlands}

Wetlands play essential ecological, social and economic roles. ${ }^{2,11}$ According to Kadafa, ${ }^{69}$ wetland has the tendency to break down and assimilate pollutants. In the Niger Delta, the wetland resources is essential because it is a source of fuel wood, timbers etc used for art and construction works, breeding ground for several wildlife, nestling arena for migratory birds, spawning place for different fish species, and source of plants with insecticidal and antimicrobial properties. ${ }^{2,30,70}$ The region has been widely reported as area of endemic species of biodiversity including plants, mammals, birds, reptiles, amphibians. ${ }^{70}$ The Niger Delta ecosystem forest products including food, fuel wood, protein sources - crabs, crayfish, fishes, prawn, periwinkles, snails and other raw materials. ${ }^{22,30}$

Some of the biodiversity including plants and animal has some medicinal uses. This is because fats, oil, skin of some animals are used in treating some certain diseases in human in addition to their food purposes. For instance, Costa-Neto ${ }^{71}$ which stated that the tusks of hippo (Hippopotamus amphibious) can be used for aphrodisiacs and ornamentals, and the fat extracted from manatee (Trichechus senegalensis) can be used to cure rheumatism, boils, and backache. Costa-Neto ${ }^{71}$ also reported that the blood of the black caiman (Melanosuchus niger) can used to treat epilepsy and stroke; ants of the genus Pseudomyrmex can be used for the treatment of toothache and reliving painful joints pains; the various anatomical parts of the rattlesnake (Crotalus sp.) are used for the treatment of infirmities ranging from boils to bronchitis; the fresh manure of a dromedary (Camelus dromedaries) is applied externally on the affected parts to alleviate arthritis; the fats of lion (Panthera leo) and hyena (Crocuta crocuta) can be used to alleviate abdominal pains; hooves of duikers (Sylvicapra grimmia) and antelopes (Hippotragus equines) are used as special container for concoctions with herbs to appease traditional gods and witches. Different parts of animal are used in traditional medicine. ${ }^{72}$ Costa-Neto ${ }^{71}$ noted that the hooves, tusks, bones, feathers, skins of most mammals have serious medicinal properties. Some of the animals mentioned by Costa-Neto ${ }^{71}$ have been previously reported in the Niger Delta region. However, most of them have not been sighted in the region within the last 20 decades.

Several plants found in Niger Delta region have been widely reported to have medicinal purposes. In a review study by Bassey \& Izah, ${ }^{73}$ several Nigerian plants are potent against mosquito at several stages of development. Some of the plants mentioned by the authors are found in the Niger Delta region. Several plants have been reported to have antimicrobial effects including Musanga cecropioide, ${ }^{74}$ Vitex grandifolia ${ }^{75}$ Alstonia boonei, ${ }^{76}$ Alchornea cordifolia, ${ }^{77}$ and many other species of plants. Some of this plants species have emerged as credible source for synthesis of new medicine ${ }^{78,79}$ According to Costa-Neto, ${ }^{71}$ Izah \& Seiyaboh, ${ }^{72}$ Izah et al., ${ }^{78}$ indigenous knowledge of biological resources especially as it's related to its health benefits aid in their exploitation for its commercial commercialization. Several part of mangrove plant is used as poles communication lines, foundation piles, local sign posts, the saplings and twigs mud and thatch house construction. ${ }^{80}$ James et al., ${ }^{81}$ reported that Niger Delta mangroves have social values including therapeutic, amenity, spiritual, heritage and existence values.

According to Ohimain \& Akinnibosun, ${ }^{82}$ a unique wetland is developed from the interaction of soil, vegetation and hydrology of an area. The forest acts as a shield for soils beneath, especially from effects of natural factors such as heavy rainfall, high temperatures and destructive winds and erosion. ${ }^{83}$ According to Eleanya et al., ${ }^{80}$ mangroves acts as buffer against wave action, aid in filtering water resources, carbon sink, and thereby minimize the effect of global warming, protection of arable land and coastal region, and minimizing the effect of erosion and flooding. 


\section{Challenges and threats of the Niger delta ecosystem}

Urbanization, industrialization, intense agricultural practices, deforestation, use of chemical based fertilizers, pesticides, emission from the consumption of fossils fuel are the major factor leading to environmental degradation. Uluocha \& Okeke, ${ }^{10}$ Izah et al., ${ }^{2}$ Nwankwoala ${ }^{9}$ listed human activities and biogeophysical effects including positive population growth rate, urbanization/ industrialization, emission emanating from industrial activities such as mining, oil and gas activities, unrestrained tilling of soil for crop production, over-grazing, logging/lumbering, unmatched land reclamation, dam construction, physical infrastructure, erosion, sea rising, alien invasion, sand storm, desertification, droughts etc. as important factors threatened wetland resource of the Niger Delta region.

The rate of deforestation is high leading to loss of valuable plants species and animal habitats thereby exposing them to excessive exploitation. According to Ogboru \& Anga, ${ }^{83}$ World Fact book in 2005 reported that Nigeria as one of the leading country with high forest loss in the world of 3.3\%, and $37.7 \%$ since 1990. Between 1990 to 2005 Nigeria lost $79 \%$ of her forest thereby challenging its sustainability. ${ }^{83}$ In the environment, different species of biodiversity comprising of plants and animals are needed to ecological balance in the food web and chains ${ }^{83}$ But the rate of degradation or loss is high without corresponding replacement, thereby causing a major threat to humans and the environment itself. Some of the effects of environmental degradation include increased rate and intensity of erosions, flooding, etc.

The loss of forest resources through excessive exploitation, illegal poaching, deforestation, uses of chemicals, logging, bush burning is having an impacts on the diversity, composition, abundance of biodiversity in the Niger Delta. Thereby predisposing majority of species to IUCN criteria such as (threatened, endangered, critically endangered and extinction). As such some species have not been seen in the region with the last 4-5 decades thereby assuming that they have gone on extinction in the region. ${ }^{11,12}$ Specifically, between $1987-$ 2011, the region has loss many of its forest resources through land use. The decline in the forest is affecting bare ground $\left(195 \mathrm{~km}^{2}\right)$, water $\left(132 \mathrm{~km}^{2}\right)$, farmlands $\left(8338 \mathrm{~km}^{2}\right)$, urban area $\left(2898 \mathrm{~km}^{2}\right)$, mangroves $\left(1535 \mathrm{~km}^{2}\right)$, freshwater forest $\left(1424 \mathrm{~km}^{2}\right)$ and lowland rainforest $\left(8324 \mathrm{~km}^{2}\right) .{ }^{30}$ Among the major ecosystem, loss is more in the lowland rain forest. ${ }^{84}$ This could be due to potential of agricultural activities in the land of lowland rainforest. ${ }^{85}$ Specifically Ayanlade \& Drake ${ }^{84}$ reported that $40 \%, 30 \%$ and $11 \%$ of the lowland rainforests, freshwater swamp forest reserves mangrove forests, respectively have been loss in the last 3 decades in the Niger Delta region. Enaruvbe \& Atafo ${ }^{86}$ reported that high rate of deforestation, loss of cropland/secondary vegetation and water body is leading to environmental degradation thereby enhancing loss of biodiversity and forest goods and services.

Several human activities including oil and gas exploration, dredging, invasive plant infestation and wetland reclamation in addition to increased exploration, population growth and weak governance have led to increase case of water pollution/contamination, fish migration, and shrinkage of wetland region of the Niger Delta. ${ }^{13}$

Due to the importance of medicinal animals, excessive exploitation could pose danger to traditional health practitioners that use different parts of the aquatic mammals for treatment. ${ }^{72}$ Similarly, Costa-Neto ${ }^{71}$ has stated that poaching of wild animals for meat and medicinal purposes is a major problem in all the game reserves and national parks in Africa.

\section{Conclusion and the way forward}

Mangroves, lowland rainforest and freshwater forest ecosystems of the Niger Delta which is essential for the survival of several families of plants and animal under intense threat due to human activities in the region. This is having impact on the biodiversity of the ecosystem, thereby predisposing some species to IUCN classification such as threatened, endangered and extinction. This study showed that lowland rainforest is the major ecosystem being loss. The loss of ecosystem due to human activities is a threat to the ecological role of the Niger Delta forest including protection of shoreline, breeding ground for several migratory birds, spawning group to both shell and fin fish, habitats to several endemic wildlife. Hence there need for improved enforcement, surveillance of the various the international legislations/ law/ treaties concerning the protection and conservation of biodiversity in which Nigeria is part of, as well as national and local law promoting biodiversity conservation.

\section{Acknowledgments}

None.

\section{Conflict of interest}

There is no conflict of interest to declare regarding the publication of this paper.

\section{References}

1. Idu AJ. Threats to Water Resources Development in Nigeria. $J$ Geol Geophys. 2015;4:205.

2. Izah SC, Angaye $\mathrm{CN}$, Aigberua $\mathrm{AO}$, et al. Uncontrolled bush burning in the Niger Delta region of Nigeria: potential causes and impacts on biodiversity. International Journal of Molecular Ecology and Conservation. 2017;7(1):1-15.

3. Izah SC, Srivastav AL. Level of arsenic in potable water sources in Nigeria and their potential health impacts: A review. Journal of Environmental Treatment Techniques. 2015;3(1):15-24.

4. Izah SC, Angaye TCN. Heavy metal concentration in fishes from surface water in Nigeria: Potential sources of pollutants and mitigation measures. Sky Journal of Biochemistry Research. 2016;5(4):31-47.

5. Agedah EC, Ineyougha ER, Izah SC, et al. Enumeration of total heterotrophic bacteria and some physico-chemical characteristics of surface water used for drinking sources in Wilberforce Island, Nigeria. Journal of Environmental Treatment Techniques. 2015;3(1):28-34.

6. Izah SC, Bassey SE, Ohimain EI. Geo-accumulation index, enrichment factor and quantification of contamination of heavy metals in soil receiving cassava mill effluents in a rural community in the Niger Delta region of Nigeria. Molecular Soil Biology. 2017;8(2):7-20.

7. Izah SC, Bassey SE, Ohimain EI. Assessment of pollution load indices of heavy metals in cassava mill effluents contaminated soil: a case study of small-scale cassava processing mills in a rural community of the Niger Delta region of Nigeria. Bioscience Methods. 2017;8(1):1-17.

8. Izah SC, Angaye TCN, Ohimain EI. Environmental Impacts of Oil palm processing in Nigeria. Biotechnological Research. 2016;2(3):132-141.

9. Nwankwoala HO. Case Studies on Coastal Wetlands and Water 
Resources in Nigeria. European Journal of Sustainable Development. 2012;1(2):113-126

10. Uluocha N, Okeke I. Implications of wetlands degradation for water resources management lessons from Nigeria. GeoJournal. 2004;61:151-154.

11. Izah SC, Seiyaboh EI. Changes in the protected areas of Bayelsa state, Nigeria. International Journal of Molecular Evolution and Biodiversity. 2018;8(1):1-11.

12. Izah SC, Aigberua AO, Nduka JO. Factors affecting the population trend of biodiversity in the Niger Delta region of Nigeria, International Journal of Avian and Wildlife Biology. 2018;3(3):206-214.

13. Adekola O, Mitchell G. The Niger Delta wetlands: threats to ecosystem services, their importance to dependent communities and possible management measures. International Journal of Biodiversity Science, Ecosystem Services \& Management. 2011;7(1):50-68.

14. Scott DA. A directory of Asian wetlands. IUCN, Gland and Cambridge; 1989. $1181 \mathrm{p}$.

15. Ramsar Convention Secretariat. Information Sheet on Ramsar Wetlands (RIS): Apoi Creek; 2007.

16. Ohimain EI, Akinnibosun HA. Assessment of wetland hydrology, Hydrophytic vegetation and hydric soil as indicators for wetland determination, Tropical Journal of Environmental Science and Health. 2007;10(1):1-11.

17. Olalekan EI, Abimbola LM, Saheed M, et al. Wetland Resources of Nigeria: Case Study of the Hadejia-Nguru Wetlands. Poult Fish Wildl Sci. 2014;2:123.

18. Emma-Okafor LC, Ibeawuchi II, Obiefuna JC. Biodiversity Conservation for Sustainable Agriculture in Tropical Rainforest of Nigeria. New York Science Journal. 2010 ;3(1):81-88.

19. Federal Republic of Nigeria (FRN). Fourth National Biodiversity Report, Abuja; 2010.

20. Ayanlade A, Proske U, Assessing wetland degradation and loss of ecosystem services in the Niger Delta, Nigeria. Marine and Freshwater Research. 2015;67(6):828-836.

21. Ibimilua AF. Biodiversity-ecosystem management and sustainable development in Ekiti state, Nigeria. British Journal of Humanities and Social Sciences. 2013;9(1):35-44.

22. Igu NI, and Marchant, R (2017) Freshwater swamp forest use in the Niger Delta: perception and insights. Journal of Forest Research, 2017;22(1):44-52.

23. Ogbe MG. Managing the environmental challenges of the oil and gas industry in the Niger Delta, Nigeria. Journal of Life Science. 2011;1(1):1-17.

24. Ohimain EI. Environmental impacts of petroleum exploration dredging and canalization in the Niger Delta. In: Akpotoe AS, Egboh SH, editors. Five decades of oil production in Nigeria: impact on the Niger Delta, 2012; pp. 391-405.

25. Spalding MF, Blasco F, Field C. World mangrove ecosystem atlas, The international Society of mangrove ecosystem (ISME), Japan. 1997.

26. Akachi O. Social Consequences of Environmental Change in the Niger Delta of Nigeria. Journal of Sustainable Development. 2011;4(2):123135 .

27. Okonkwo CNP, Kumar L, Taylor S. The Niger Delta wetland ecosystem: What threatens it and why should we protect it?. African Journal of Environmental Science and Technology. 2015;9(5):451-463.

28. Ajao EA, Anurigwo S. Land-based sources of pollution in the Niger
Delta, Nigeria. Ambio. 2002;31(5):442-445.

29. Blench R. The mammals of the Niger Delta in Nigeria. The Kay Williamson Education Foundation (KWEF); 2007.

30. Ayanlade A. Remote Sensing of Environmental Change in the Niger Delta, Nigeria. PhD thesis submitted to Department of Geography, School of Social Sciences and Public Policy, King's College London, University of London; 2014.

31. Niger Delta Regional Development Master-plan (NDRDMP). Niger Delta regional master plan. Facilitated by the Niger Delta Development Commission (NDDC) in partnership with the nine states' governments, LGAs, Oil Companies, Civil Society Organizations and Communities in the Niger Delta; 2006.

32. Jamabo N, Chinda A. Aspects of the Ecology of Tympanotonus fuscatus var fuscatus (Linnaeus, 1758) in the Mangrove Swamps of the Upper Bonny River, Niger Delta, Nigeria. Current Research Journal of Biological Sciences. 2010;2(1):42-47.

33. Ogamba EN, Izah SC, Omonibo E. Bioaccumulation of hydrocarbon, heavy metals and minerals in Tympanotonus fuscatus from coastal region of Bayelsa state, Nigeria, International Journal of Hydrology Research. 2016;1:1-7

34. Ohimain EI, Otobotekere D, Biriduba W. Unsustainable Exploitation of Freshwater Wetland Turtles and Tortoises in Central Niger Delta. International Journal of Environmental Monitoring and Analysis. 2014;2(2):57-64.

35. Bob-Manuel FG. A prelimenary study on the population estimation of the periwinkles Tympanotonus fuscatus (Linnaeus, 1758) and Pachymelania aurita (Muller) at the Rumuolumeni mangrove swamp creek, Niger Delta, Nigeria. Agriculture and Biology Journal of North America. 2012;3(6):265-270.

36. Seiyaboh EI, Inyang IR, Izah SC. Spatial Variation in Physico-chemical Characteristics of Sediment from Epie Creek, Bayelsa State, Nigeria. Greener Journal of Environment Management and Public Safety. 2016;5(5):100-105.

37. Seiyaboh EI, Izah SC, Oweibi S. Assessment of Water quality from Sagbama Creek, Niger Delta, Nigeria. Biotechnological Research. 2017;3(1):20-24.

38. Seiyaboh EI, Izah SC, Oweibi S. Physico-chemical Characteristics of Sediment from Sagbama Creek, Nigeria. Biotechnological Research. 2017;3(1):25-28.

39. Seiyaboh EI, Inyang IR, Izah SC. Seasonal Variation of PhysicoChemical Quality of Sediment from Ikoli Creek, Niger Delta. International Journal of Innovative Environmental Studies Research. 2016;4(4):29-34.

40. Ogamba EN, Izah SC, Toikumo BP. Water quality and levels of lead and mercury in Eichhornia crassipes from a tidal creek receiving abattoir effluent, in the Niger Delta, Nigeria. Continental Journal of Environmental Science. 2015;9(1):13-25.

41. Ogamba EN, Izah SC, Ofoni-Ofoni AS. Bioaccumulation of Chromium, Lead and Cadmium in the bones and tissues of Oreochromis niloticus and Clarias camerunensis from Ikoli creek, Niger Delta, Nigeria. Advanced Science Journal of Zoology. 2016;1(1):13-16.

42. Ogamba EN, Seiyaboh EI, Izah SC, et al. Water quality, phytochemistry and proximate constituents of Eichhornia crassipes from Kolo creek, Niger Delta, Nigeria. International Journal of Applied Research and Technology. 2015;4(9):77-84.

43. Ogamba EN, Ebere N, Izah SC. Heavy Metal Concentration in Water, Sediment and Tissues of Eichhornia crassipes from Kolo Creek, Niger Delta. Greener Journal of Environment Management and Public Safety. 2017;6(1):1-5. 
44. Daka ER, Amakiri-Whyte B, Inyang IR. Surface and groundwater in some oil field communities in the Niger Delta: implications for domestic use and building construction. Research Journal of Environmental and Earth Sciences. 2014;6(2):78-84.

45. Ogamba EN, Izah SC, Oribu T. Water quality and proximate analysis of Eichhornia crassipes from River Nun, Amassoma Axis, Nigeria. Research Journal of Phytomedicine. 2015;1(1):43-48.

46. Ogamba EN, Ebere N, Izah SC. Levels of lead and cadmium in the bone and muscle tissues of Oreochromis niloticus and Clarias camerunensis. EC Nutrition. 2017;7(3);117-123.

47. Aghoghovwia OA, Miri FA, Izah SC. Impacts of Anthropogenic Activities on Heavy Metal Levels in Surface Water of Nun River around Gbarantoru and Tombia Town, Bayelsa State, Nigeria. Annals of Ecology and Environmental Science. 2018;2(2):1-8.

48. Nyananyo BL, Gijo AH, Ogamba EN. The physico-chemistry and distribution of water hyacinth (Eichhornia crassipes) on the river Nun in the Niger Delta. J Appl Sci Environ Manage. 2007;11:133-137.

49. Seiyaboh EI, Izah SC, Bokolo JE. Bacteriological quality of water from river nun at Amassoma Axises, Niger Delta, Nigeria. ASIO Journal of Microbiology, Food Science \& Biotechnological Innovations. 2017;3(1):22-26.

50. Gijo AH, Hart AI, Seiyaboh EI. The Impact of Makeshift Oil Refining Activities on the Physico-Chemical Parameters of the Interstitial Water of the Nun River Estuary, Niger Delta, Nigeria. Biotechnol Res. 2016;2(4):193-203.

51. Gijo AH, Hart AI, Seiyaboh EI. The impact of makeshift oil refineries on the physico-chemistry of the sediments of the nun river estuary, Niger Delta, Nigeria. Sky J Soil Sci Environ Manage. 2017;6(1):19-25.

52. Gijo AH, Hart AI, Seiyaboh EI. The impact of makeshift oil refineries on the macro-invertebrates of the nun river estuary, Niger Delta, Nigeria. Greener J Biol Sci. 2016;6(6):112-119.

53. Ohimain EI, Akinnibosun HA. Hydrophytic vegetation indicators for wetland delineation in a rapidly expanding coastal mega city, Lagos, Nigeria. African Journal of Bioscience. 2008;1(1):95-102.

54. Akani GC, Politano E, Luiselli L. Amphibians recorded in forest swamp areas of the River Niger Delta (southeastern Nigeria), and the effects of habitat alteration from oil industry development on species richness and diversity. Applied Herpetology. 2004;2(1):1-22.

55. Ikemeh RA. Assessing the Population Status of the Critically Endangered Niger Delta Red Colobus (Piliocolobus epieni). Primate Conservation. 2015;29:87-96.

56. Wildlife conservation society. Saving the Niger Delta red colobus monkey from extinction: enlisting the support of local communities to help protect Apoi creek forest reserve. Stakeholder Workshop Report, Yenagoa, Nigeria; 2012.

57. Oates JF, Were JL. Niger Delta Red Colobus Monkey Procolobus epien Grubb and Powell, 1999 Niger Delta, Nigeria. 2008.

58. Akani GC, Amadi N, Eniang EA, et al. Are mammal communities occurring at a regional scale reliably represented in "hub" bushmeat markets? A case study with Bayelsa State (Niger Delta, Nigeria). Folia Zool. 2015;64(1):79-86.

59. Ohimain EI, Izah SC, Otobotekere D. Selective impacts of the 2012 water floods on the vegetation and wildlife of Wilberforce Island, Nigeria. International Journal of Environmental Monitoring Analysis. 2014;2:73-85.

60. Hamadina MK, Otobotekere D, Anyanwu DI. Impact assessment and biodiversity considerations in Nigeria: a case study of Niger Delta
University campus project on wildlife in Nun River forest reserve. Management of Environmental Quality: An International Journal. 2007;18(2):179-197.

61. Amadi N, Akani GC, Micheloni P, et al. Distribution, habitat ecology and conservation status of the Two-spotted Palm Civet Nandinia binotata (Carnivora, Nandiniidae) in south-eastern Nigeria. Small Carnivore Conservation. 2016;52\&53:24-38.

62. Akani GC, Aifesehi PEE, Petrozzi F, et al. Diversity of terrestrial vertebrates in Taylor creek forest reserve, an area of high environmental value in the River Niger Delta (Bayelsa State, Nigeria). Vie et milieu Life and environment. 2014;64:59-68.

63. Lameed GA. Potential impact on biodiversity in Kwale's forest reserve by power plant establishments. African Journal of Food, Agriculture, Nutrition and Development. 2009;9(9):1878-1900.

64. African Center for Economic Transformation (ACET). Bushmeat and the future of protein in West Africa. West Africa Trends Newsletter. 2014;(9):1-13.

65. Okore O, Avaoja D, Nwana I. Edible Insects of the Niger Delta Area in Nigeria. Journal of Natural Sciences Research. 2014;4(5):1-9.

66. Ubom RM. Ethnobotany and Biodiversity Conservation in the Niger Delta, Nigeria. International Journal of Botany. 2010;6:310-322.

67. Eludoyin OS, Oladele AT, Iyanda OM. Mapping and Assessment of Ethno-Medicinal Trees in Built Up Areas - University of Port Harcourt, Nigeria. South-East European Forestry. 2015;6(1):129-140.

68. Uzodimma DE. Medico-Ethnobotanical inventory of Ogii, Okigwe Imo State, South Eastern Nigeria - I. Global Advanced Research Journal of Medicinal Plants. 2013;2(2):30-44.

69. Kadafa AA. Environmental Impacts of Oil Exploration and Exploitation in the Niger Delta of Nigeria. Global Journal of Science Frontier Research Environment and Earth Sciences. 2012;12(3):19-27.

70. Ohimain EI. Wetlands protection for environmental sustainability in the Niger Delta of Nigeria. Nigerian Journal of Plant Protection. 2009;23:1-15.

71. Costa-Neto EM. Animal-based medicines: biological prospection and the sustainable use of zootherapeutic resources. Annals of the Brazilian Academy of Sciences. 2005;77(1):33-43.

72. Izah SC, Seiyaboh EI. Challenges of wildlife with therapeutic properties in Nigeria; a conservation perspective. International Journal of Avian \& Wildlife Biology. 2018;3(4):259-264.

73. Bassey SE, Izah SC. Nigerian plants with insecticidal potentials against various stages of mosquito development. ASIO Journal of Medical and Health Sciences Research. 2017;2(1):7-18.

74. Kigigha LT, Biye SE, Izah SC. Phytochemical and antibacterial activities of Musanga cecropioides tissues against Escherichia coli, Pseudomonas aeruginosa, Staphylococcus aureus, Proteus and Bacillus species. International Journal of Applied Research and Technology. 2016;5(1):100-107.

75. Epidi JO, Izah SC, Ohimain EI, et al. Phytochemical, antibacterial and synergistic potency of tissues of Vitex grandifolia. Biotechnological Research. 2016;2(2):69-76

76. Epidi JO, Izah SC, Ohimain EI. Antibacterial and Synergistic Efficacy of Extracts of Alstonia boonei Tissues. British Journal of Applied Research. 2016;1(1):21-26.

77. Kigigha LT, Atuzie MN. Assessment of traditional medicinal application of Alchornea cordifolia. African Journal of Biotechnology. 2012;11(8):2083-2086 
78. Izah SC, Uhunmwangho EJ, Eledo BO. Medicinal potentials of Buchholzia coriacea (wonderful kola). Medicinal Plant Research. 2018;8(5):27-43.

79. Izah SC, Zige DV, Alagoa KJ, et al. Antibacterial Efficacy of Aqueous Extract of Myristica fragrans (Common Nutmeg). EC Pharmacology and Toxicology. 2018;6(4):291-295.

80. Eleanya K, Agbeja BO, Ijeomah HM. Socio-Economic Importance of Mangrove Forests In Akassa Island of Niger Delta, Nigeria. Production Agriculture Technology. 2015;11(1):1-11.

81. James GK, Adegoke JO, Osagie S, et al. Social valuation of mangroves in the Niger Delta region of Nigeria, International Journal of Biodiversity Science. Ecosystem Services \& Management. 2013;9(4):311-323.

82. Ohimain EI, Akinnibosun HA. Hydrophytic vegetation indicators for wetland delineation in coastal swamp, southwestern Nigeria. African
Journal of Pure and Applied Science. 2010;3(1):73-81.

83. Ogboru I, Anga RA. Environmental Degradation And Sustainable Economic Development In Nigeria: A Theoretical Approach. Journal of Economics. 2015;3(6):1-13.

84. Ayanlade A, Howard MT. Understanding changes in a Tropical Delta: A multi-method narrative of landuse/land cover change in the Niger Delta. Ecological Modelling. 2017;364(24):53-65.

85. Ayanlade A, Drake N. Forest loss in different ecological zones of the Niger Delta, Nigeria: evidence from remote sensing. GeoJournal. 2016;81:717-735.

86. Enaruvbe GO, Atafo OP. Analysis of deforestation pattern in the Niger Delta region of Nigeria. Journal of Land Use Science. 2016;11(1):113130 